\title{
EL “OTRO” EN “GRANADA [TRILOGÍA]” DE RADWA ASHUR
}

\author{
The "Other" in "Granada [trilogy]" of Radwa Ashur
}

Nozad Heshmat Kasem*

\section{RESUMEN}

La presente investigación es un estudio de la imagen del "Otro" en la obra de la escritora egipcia Radwa Ashur "Granada [trilogía]", que se inserta en el marco de la literatura comparada y, dentro de ella, en la imagología, corriente que aborda la representación de la alteridad por medio de diversas formas de expresión artística, entre las que se incluye la literaria. Radwa Ashur en esta obra trata un tema tan relevante como la Reconquista de Granada y el momento traumático en la historia, tanto árabe como española, marcado por la expulsión y la conversión forzada de los musulmanes. De esta manera, tomando como base la teoría imagológica de Jean-Marc Moura y la hermenéutica de Paul Ricour, se examinará tanto la imagen ideológica como la utópica que representa la autora del otro "heteroimagotipo" y de sí misma "autoimagotipo".

Palabras clave: Imagología, heteroimagotipo, autoimagotipo, ideología y utopía.

\begin{abstract}
The present work is a study of the image of the "Other" in the novel "Granada [trilogy]", of the Egyptian writer Radwa Ashur. This study is inserted into the framework of comparative literature, specifically in the imagology stream which addresses the representation of "otherness" through various forms of artistic expression. Radwa Ashur in this work addresses a traumatic moment in both Arabic and Spanish history, during the re-conquest of Granada. This moment is marked by the expulsion and forced conversion of Muslims. Thus, based on the imagology theory of Jean-Marc Moura and the hermeneutics of Paul Ricour, the present study examines both ideological and utopian images represented by the author, of the other (heteroimage) and of itself (auto-image).
\end{abstract}

Key Words: Imagology, hetero-image, auto-image, ideology and utopia.

Universidad de El Cairo, Profesora, Departamento de Lengua y Literatura Hispánicas. Egipto.

Correo electrónico: nozad2005@gmail.com.

Recepción: 11/11/2014. Aceptación: 3/3/2015. 


\section{Historia e intrahistoria}

Son pocos los escritores que, como la aquí estudiada, atesoran la habilidad para guardar un equilibrio entre lo imaginativo y la transmisión de ideas, evitando así que sus obras se conviertan en tediosas obras de tesis. De este modo uno de los rasgos que hacen de "Granada [trilogía]" una obra de referencia dentro de la literatura cuyo tema es "Al Ándalus", es su capacidad para aunar, en una armónica simbiosis, ficción y realidad. La profesora Radwa Ashur publicó en 1994 tres novelas, Granda, Mariama y La Partida, unidas bajo el título de "Granada [trilogía]". Esta obra narra la tragedia de una familia morisca de Albaicín, entre 1491 y 1609, compuesta por tres generaciones: la del abuelo "Abu Yáfar", la de sus nietos "Hassan" y" Salima", y finalmente la de su bisnieto "Ali".

Pero, ¿por qué ha elegido la autora esta etapa crítica de la historia, tanto de los árabes como de los castellanos, para tratar el tema del "otro"?, ¿ha querido la autora relacionar el pasado y el presente? Según Edward Said (1996:35), entre las estrategias más corrientes de interpretación del presente se encuentra la invocación del pasado. Lo que sostiene esa invocación no es sólo el desacuerdo acerca de lo que sucedió, acerca de lo que realmente fue ese pasado, sino la incertidumbre acerca de si el pasado realmente lo es, si está concluido o si continúa vivo, quizá bajo distintas formas. No existe una línea divisoria y definida en que el pasado pueda ser aislado del presente. El pasado y el presente se informan mutuamente; cada uno implica al otro, cada uno coexiste con el otro.

Según las propias palabras de la autora:

Tuve que leer muchísimo. Leía para la lectura y no la escritura. Buscaba en los libros algo que no lo sabía. Leía como si quisiera comprender, o sea, quisiera huir de la tristeza del presente, que no podía aguantar más, hacia el pasado. Y cuanto más leía, los libros de historia me revelaban las características de los andalusíes oprimidos y marginados. (Ashur, 2000).

La autora visitó Andalucía por primera vez en 1993, y esta visita le brindó la oportunidad de contemplar la Granada actual, imaginar cómo era en el pasado y pintar el espacio donde ocurrieron los acontecimientos de su novela. El marco general de "Granada: [Trilogía]" son acontecimientos históricos documentados (la caída de Granada, el tratado de la extradición de Granada y Alambra, la quema de los libros, los autos de fe, la revolución de Albaicín, la diáspora de los "moros" hasta su expulsión final en 1609). Pero la autora no se quedó satisfecha solo con el marco histórico, sino que también le añadió la descripción de la vida cotidiana andalusí: el vestido, la comida, las casas, los baños públicos, los cuentos populares, las ceremonias matrimoniales, etc. Todos estos elementos se mezclaron en la trama de la vida de los personajes de la novela. Es decir, se puede conocer mejor y de forma más fiel la historia de un pueblo a través de su intrahistoria que de su historia oficial. Además, podemos decir que este texto está suspendido entre la historia restaurada y la visión de una autora que pertenece a la segunda mitad del siglo XX. De este modo, la autora afirma la misma idea utilizando esta metáfora: "El texto es una trenza en la que se entretejen mechones de historia y otros imaginados, y algunas veces los históricos se derritieron totalmente en los imaginados". (Ashur, 2000).

Cabe mencionar aquí que la autora afirma que la idea de su novela nació cuando vio en las noticias una mujer iraquí desnuda corriendo en el medio del bombardeo estadounidense de su país. Radwa Ashur empieza su novela con esta misma mujer desnuda, pero en este caso andalusí, paseando por las calles de Granada, adivinando la caída de la ciudad. Así la profesora Radwa Ashur relaciona el pasado y el presente árabes a través del "Imperialismo", tanto moderno (los Estados Unidos, potencia principal del momento) como antiguo (Europa). Es muy importante en este sentido tener en cuenta el origen de la autora de la obra estudiada, cuyo país sufrió durante muchos años del imperialismo turco, francés y británico, y que actualmente está luchando contra el imperialismo moderno que intenta dominar todo el Medio Oriente. Además, no podemos ignorar el hecho de que nuestra autora 
es la esposa de Moryd Albargouzy, el famoso poeta palestino exiliado de su país en 1967.

\section{Análisis imagológico de la Trilogía}

La imagología, según José Manuel López De Abiada (2005: 13), tiene que ver con las imágenes mentales que nos hacemos de los demás y, en especial, de los llamados "diferentes", es decir, sistemas culturales distintos y de otros pueblos, naciones, etnias o razas, independientemente de su grado de correspondencia con la realidad. Manuel Sánchez Romero observa, por otra parte, una evolución muy positiva en el campo de la teoría imagológica, desde hace dos décadas, sobre todo en Francia. (Romero, 2005:9-28) Destaca sobre todo un investigador perteneciente a esta nueva escuela francesa: Jean-Marc Moura. Los esfuerzos del imagólogo francés son destacados tanto para el afianzamiento de los conceptos teóricos como para su puesta en práctica en la interpretación textual imagológica contemporánea.

La teoría de Jean-Marc Moura propone investigar la imagen centrándose en tres aspectos temáticos. Primero, abordar el término imagen como imagen de lo (o del) extraño o extranjero. En segundo lugar, investigar la imagen como producto de una nación, cultura o sociedad (el imaginario social). Y por último, analizar la imagen como un producto creado por un autor determinado. Sin embargo, sería erróneo analizar por separado cada uno de estos aspectos, ya que sería inexacto considerar la imagen, bien como un reflejo de la realidad o bien como un aspecto literario, que no tiene relación alguna con el contexto social. Así, este estudio analiza, mediante la "Trilogía", la imagen que tenía el castellano, durante aquella época, del "moro", y viceversa. Además, estudia la imagen que tenía cada pueblo de sí mismo, teniendo en cuenta el contexto social y cultural de la autora de la obra.

Pero por la excesiva importancia otorgada a los aspectos sociales y culturales en la imagología tradicional que considera que la literatura es un mero reflejo de la sociedad, Moura propone un método basado en la teoría de la hermenéutica de Paul Ricoeur, sobre todo lo que se refiere a sus reflexiones sobre la imagen y la fantasía.

Según Ricoeur, el componente histórico y social que tiene cualquiera nación, y la posición central que éste ocupa dentro de la reflexión imagológica justifican la conexión que esta rama del comparatismo debe mantener con las ciencias sociales. Así, hay que comprender el discurso imagológico, insertándolo en un contexto de elementos extraliterarios. "Las imágenes no son un registro directo de una realidad por parte de un autor, sino que son transmitidas por el grupo o sociedad a los que pertenecen". (Romero, 2005: 13)

Por todo ello, según Moura, es necesario estudiar el contexto cultural del cual surge la imagen. Jean-Marc Moura propone investigar la imagen como juicios de valor emitidos sobre una cultura ajena o sobre la propia, lo que constituye lo que Ricoeur denomina "imaginario social", marcado por su bipolaridad entre la identidad y la alteridad. Es el lugar donde confluyen las imágenes por medio de los cuales una sociedad mira a sí misma y a las demás. La imagen literaria de lo extraño, transmitida social y culturalmente, no es considerada en la teoría de Ricoeur como reflejo de la realidad. Al contrario, es necesario investigar esta cuestión de forma interdisciplinar para poder analizar las relaciones entre la literatura y el alcance del imaginario social, fenómeno que Ricoeur distingue en los textos literarios con los términos ideología y utopía (Ricoeur 1989 y Ricoeur 2001).

\subsection{Imagen, estereotipo y mito}

Para analizar el imagotipo del español que representa Radwa Ashur en su novela resulta conveniente primero enunciar cuáles son los elementos diferenciadores y los nexos entre los tres tipos de representaciones que afloran cuando se alude al Otro, es decir, imagen, estereotipo y prejuicio. 
La imagen es idea u opinión general e impersonal de vasta difusión acerca de una nacionalidad, o de una región o de una ciudad de mítico prestigio como, en este caso, Granada. Asimismo, es imagen para algunos, el amiente nacional o pequeño mundo que construye el conjunto de una obra de imaginación, como es la "Carmen" de Mérimée. (Abiada, 2005:24)

El estereotipo es una de las estructuras cognitivas que intervienen en el conocimiento social de la realidad. Es una forma particular de la imagen en el sentido en el que ésta ha sido propuesta. Es "un conjunto de creencias compartidas acerca de los atributos personales que poseen los miembros de un grupo". (Morales, 1996: 163) Tales creencias o ideas son comúnmente compartidas por todos los miembros de un mismo grupo social y justifican las acciones hacia los otros grupos y fomentan una identidad social positiva.

A diferencia de los estereotipos que tienen un desarrollo cognitivo y que se producen de hechos reales en la vida cotidiana, los prejuicios son "las opiniones, malas o buenas, que una persona tiene con anticipación”. (Abiada: 25) Así, son opiniones prejuzgadas. Manuel Sánchez Romero añade otro aspecto muy importante a la definición del prejuicio, al decir que éste es generalmente negativo. Además, tales prejuicios negativos pueden desembocar en imagotipos hostiles, así por ejemplo, "los prejuicios que se generan a resultas de una guerra o de una situación socialmente crítica". (Romero: 23 )

Por otro lado, afirma Manuel Sánchez Romero que las imágenes (imagotipos) consisten en dos partes: la imagen que una nación tiene de sí misma (autoimagotipo) y la imagen proyectada por los demás (heteroimagotipo). Pues el término imagotipo es más amplio que la imagen. El imagotipo consta de varios elementos, entre ellos las imágenes, los estereotipos o prejuicios. Además, no se trata de una representación directa de la realidad como ocurre con el término de imagen.

Los imagotipos se refieren normalmente a opiniones generales, por ejemplo a prejuicios, estereotipos (negativos o positivos), imágenes o bien una mezcla de estos elementos, poseen una función ideológica o utópica y pueden tener una evolución histórica.(Romero: 24)

Esto explica por qué la imagología comparada sustituyó el término "imagen" por el "imagotipo".

Después de explicar la diferencia entre estos conceptos, es importante mencionar aquí la graduación que representa la "Trilogía" desde el estereotipo y el prejuicio, hasta llegar al imagotipo final.

Muestra de ello es la narración de la primera parte de la trilogía, cuando el abuelo Abu Yáfar dice a su nieto Hassan que los castellanos "raptan a los niños árabes y los venden en los zocos como si fueran burros". (Ashur, 2008:28) Abu Yáfar todavía no ha sido testigo de semejantes actos por parte de los castellanos, solamente había oído de sus crímenes contra los árabes de las ciudades vecinas. El niño no puede entender cómo ni por qué una persona hace a otra tal cosa. Además, el niño añade que no ve en los soldados algo que despierte el miedo o la aversión. Son hombres normales como los árabes, salvo la piel rosada y el vestido diferente. Para el abuelo, el soldado castellano es un "colonizador", con todas las connotaciones que tiene la palabra. Sin embargo, los niños rechazan los prejuicios irracionales de los viejos, implantados por la tradición. Rechazan atribuir a los castellanos características que, para ellos, no corresponden a una verdad comprobable.

Ahora empieza la segunda fase del proceso. La inocencia de los niños no permite imaginar ni creer la crueldad de la colonización. No obstante, se percibe el choque en la escena del desfile de Cristóbal Colón. Aquí también se utiliza la graduación. Los niños salen de su casa entusiasmados para ver al héroe Cristóbal Colón el cual había descubierto el "Nuevo mundo". Así pues, aparecen los soldados castellanos con sus coloradas banderas, sus vestidos y sombreros decorados. Tal apariencia llama la atención y la admiración de los niños. Tras ellos el mismo Cristóbal Colón "El hombre de las barbas se quitó el sombrero negro y saludó con él a la gente, ofreciendo la mejor de sus sonrisas, como si fuera un rey de reyes". (Ashur, 2008: 39) Le 
siguen jaulas que encierran exóticas criaturas "animales y aves" que los habitantes de la Península Ibérica nunca habían visto antes. A continuación, vienen las cajas de llamativo oro, que la gente al verlos gritan "Viva Cristóbal Colón". Al final de la fila caminan los indígenas y tienen las manos atadas a la espalda. La apariencia de los indígenas presos evocó la tristeza de los niños y la burla de los castellanos. La admiración y entusiasmo de los niños al principio del desfile es sustituida por la tristeza y la falta de comprensión de las risas de los castellanos.

Ahora aparece un rasgo diferenciador del estereotipo, que es su condición de "señal", es decir, de generador de una significación que remite automáticamente a otra "señal". El estereotipo eleva las cualidades particulares de un sujeto, de una conducta o de una situación determinados a la categoría de lo general, de la esencia, procediendo a un análisis que intenta sintetizar el todo a través de una de sus partes. La conducta de los soldados castellanos hacia el desfile, cambia totalmente la imagen que tenían los niños de ellos. Desde ahora, el soldado castellano es un colonizador, y éste es una criatura cruel e insensata que establece relaciones jerárquicas y menosprecia a los demás. Al otro lado, para los castellanos, los moros son herejes, traidores y esclavos. Pero esta elevación del atributo a la categoría de esencia exige de un consenso sociocultural para que el estereotipo cuente con una fuerza normativa, y esto es lo que veremos adelante.

\subsection{El imaginario social: Ideología y Utopía}

Nutriéndose de la teoría de Ricoeur, del denominado "Imaginario social", se crea a continuación, según Moura, la tipología de la imagen literaria de lo extraño. Ésta se caracteriza por la tensión que generan los dos conceptos, ideología y utopía, entre sí, al poder mostrar tanto una función ideológica o bien una función utópico-subversiva. A continuación vamos a explicar los dos conceptos que Moura, a su vez, toma de las definiciones de Ricoeur.

\subsubsection{Ideología}

La palabra ideología fue utilizada, en los comienzos de la Ilustración, por los filósofos franceses del siglo XVIII quienes se llamaban a sí mismos ideólogos. Ellos utilizaban este concepto para referirse al análisis de las ideas elaboradas por el espíritu humano. Así pues, Carlos Marx (1818-1883) en sus años juveniles recoge el término en sus Manuscritos de 184344. (López) Para él la ideología es una manera de ver la realidad en forma distorsionada, lo cual no permite apreciar la verdad que ella contiene. En consecuencia, la primera función atribuida a la ideología es la de producir una imagen invertida de la realidad. Pero Marx influenciado por Feuerbach establece una nueva relación entre lo que son las representaciones y la realidad de la vida, que él llama "Praxis". Se pasa así del sentido restringido de la palabra ideología al sentido general. Siguiendo esta idea, hay primero, una vida real de los hombres que es su "Praxis", y después, hay un reflejo de esa vida en su imaginación, es la ideología. La ideología se convierte así en el procedimiento general mediante el cual el proceso de la vida real, la "praxis", se falsifica por medio de la representación imaginaria que los hombres se hacen de ella. (Ricour, 1984:58)

Según Teun A. van Dijk, el término "ideología" es "la base de las representaciones sociales compartidas por los miembros de un grupo [...] en la mayoría de los casos, las ideologías sirven a sus propios fines y son una función de los intereses materiales y simbólicos del grupo. Entre estos intereses, el poder sobre otros grupos puede tener un papel central, $\mathrm{y}$ por lo tanto, funcionar como condición y propósito importantes para el desarrollo de las ideologías" (2006: 116). Van Dijk añade que las ideologías también sirven para regular las prácticas sociales. Subraya, es más, el papel de las ideologías en la estabilización de formas particulares de poder y dominación. (2006: 119). Por su parte, Jean - Marc Moura define la 
"ideología" como "una necesidad imprescindible, para un grupo determinado, de construir una imagen de sí mismo "autoimagotipo", es decir, de representarse, en un sentido teatral, para reforzar una identidad propia". (Romero: 14) En esta parte del estudio vamos a analizar cómo los españoles durante aquella época, deformaron la imagen del otro "heteroimagotipo" para poder llegar a su identidad nacional.

España tuvo un papel muy importante en la formación del nuevo orden europeo como consecuencia de la unificación propugnada por los Reyes católicos. A ello venía a sumarse su incuestionable posición de potencia única con posesiones territoriales ingentes en el continente americano y su presencia en varios países europeos. Pero, como el híbrido pasado de la Península Ibérica tenía raíces pre romanas, romanas, visigodas, árabes y judías, los Reyes Católicos decidieron purgar y ocultarlos, creando una nueva identidad pura nacional. (Ortiz, 1979) Y para la difusión y hegemonía de tal identidad se creó la Inquisición, cuyo objetivo principal era velar por la limpieza de sangre y luchar contra la herejía (Islam, Judaísmo y Protestantismo). Es decir, rechazar al "Otro".

\section{- $\quad$ La función falsificadora}

Es en este sentido, que la "Trilogía" nos representa dos figuras muy importantes: el clérigo y el inquisidor. Empezaremos con el clérigo o el religioso en general. En esta obra hay dos clérigos, uno de ellos es imaginario, que es el padre "Miguel" el amo de Naim, y el otro es un verdadero personaje histórico, que es "Francisco Jiménez de Cisneros". En el caso del primero, el capítulo de su llegada a Granada empieza con una descripción de estilo poético del maravilloso verano granadino, personificando todos sus componentes. El verano es un hombre que está celebrando una boda, mientras que las flores acarician los árboles y el agua de las cascadas baja hacia las valles corriendo y riendo. Tal descripción simboliza la felicidad y la armonía en que vivía la gente de Granada. Pero el verano de aquél año, 1499, es totalmente diferente y triste con la aparición de la figura de Cisneros, el obispo de Toledo, que parece como un "enorme murciélago humano" (Ashur, 2008:51), grotesco animal nocturno. La semejanza entre los dos no reside solamente en el vestido suelto negro del cardenal que parece como las anchas alas del murciélago. Esta metáfora es común en el uso diario para expresar los actos despreciables que se conspiran en la oscuridad o en secreto con el fin de dañar a alguien. Por otra parte, el murciélago está utilizado para expresar la molestia y el agobio que palpa en Granada por la llegada de Cisneros, lo que totalmente contradice con la previa encantadora descripción del verano granadino.

Nadie en Granada lo conoce. Lo único que se sabe de él es que no es solamente un obispo, sino además un erudito. Aquí también se deja entrever la graduación en la representación de la imagen de Cisneros. Al principio, Abu Yafar y los demás confían al saber que es un sabio alfaquí, porque según el estereotipo del sabio, éste debe ser un hombre amante de la ciencia y la sabiduría. Por eso, Abu Yafar y sus amigos piensan que Cisneros debe estar en Granada para reunirse con los alfaquíes árabes e intercambiar sus conocimientos con ellos. Pero todo esto cambia al ver la verdadera cara del cardenal y enterarse del verdadero objetivo de su visita, que es empezar la tarea de acabar con la presencia árabe en la Península Ibérica. Cisneros en esta novela representa la función falsificadora de la ideología.

El castellano de aquella época para poder llegar a su propia imagen o identidad, lo hace mediante la imagen de su enemigo u oponente, que en este caso es el morisco. El castellano para fortalecer su imagen tiene que suprimir o deformar la del otro. Cisneros empieza esta tarea a través de la figura de "Hamed el Zegrí", el símbolo de la resistencia para los granadinos por haber rechazado la rendición de la ciudad de Málaga frente al ejército español y preferir el martirio, deformando la imagen ideal de Hamed, convirtiéndolo en un rebelde arrepentido. De este modo, el cardenal tortura a Hamed hasta obligarlo a convertirse al cristianismo, cambiar su nombre árabe por otro castellano y declarar su arrepentimiento. Y para dar más 
vigor e influencia a la idea de la conversión al cristianismo, lo hace por orden directa de Dios: "Ayer, mientras dormía, llegó a mí una voz que me dijo: Hamed, Dios quiere que te hagas cristiano, ésa es la voluntad de Dios, eso quiere". (Ashur, 2008: 54)

La fuerza y la confianza de cualquier pueblo se derivan de su historia y cultura. Asimismo los pueblos mantienen su propia identidad, diferente de los demás, a través de sus tradiciones. Consciente de todo esto, al castellano no le basta con mantener el pueblo bajo sus garras, se vuelve hacia el pasado, lo distorsiona, desfigura y destruye. Así, Cisneros decide empezar la segunda etapa de su plan, suprimir la identidad árabe, destruyendo su señal de superioridad. Cisneros ordena confiscar los libros de las mezquitas y escuelas de Granada, y los libreros tratan de poner a salvo los que pueden. Abu Yáfar se lleva varias docenas a una casa que tiene en Aynadamar y los esconde en el sótano. Y cuando poco después escucha la noticia de que van a quemar los libros confiscados, acude a la plaza de Bib-Rambla. Allí, todos contemplan atónitos e incrédulos cómo van amontonando los libros en el suelo. Abu Yáfar estaba destrozado, sin percibir "que Salima le apretaba la mano hasta clavarle las uñas, sin oír su voz que se alzaba insistente: 'No van a quemar los libros, ¿verdad que no, abuelo? ¡No los pueden quemar!”. Pero los quemaron, y "Salima no pudo soportar la escena (...) y se fue corriendo". (Ashur, 2008:59) El cardenal elige la plaza Bib-Rambla, el núcleo comercial y mercantil de Granada, para la quema de los libros, con el fin de asegurar que la mayoría de los granadinos atestigua la destrucción de su tradición y su identidad. Esta triste y conmovedora escena encarna la bárbara actitud de los soldados castellanos hacia los libros que simbolizan la resistencia cultural y la memoria colectiva del "Otro", representa un golpe mortal para la esperanza de Abu Yáfar el librero que ha pasado toda su vida entre los libros, y que muere esa misma noche.

El castellano sostiene y hace efectiva su visión ideológica, no sólo a través de la dominación directa y la fuerza física, sino de manera mucho más eficiente y durante largo tiempo, por medios persuasivos, los procesos cotidianos por los cuales se aseguraba la hegemonía. Es decir, a través de la imposición diaria del poder en la dinámica de la vida cotidiana. En el plano más visible, los castellanos inician a la remodelación del espacio físico: cerrar los baños públicos, convertir las mezquitas en iglesias, fundar escuelas de manejo castellano para enseñar a los niños la lengua castellana y la religión cristiana. Podemos aquí citar la metáfora de Edward Said (1996:367), quien describe al colonizador como "una madre que protege a su hijo de sí mismo, de su propio yo, de su fisiología y de su biología y de su infelicidad que es su auténtica esencia". Pero, Om Yáfar nunca ha podido entender tales leyes injustas:

¿Qué daño podía hacerle a nadie que otro ser humano
como él se abstuviera de comer carne de cerdo, que
alheñase sus manos, o concertase el matrimonio de
sus hijos fuera de la iglesia y no dentro? ¿A qué les
incordiaba tanto que una mujer como ella gastase
vestidos cortados a la morisca y no al uso de los
castellanos? ¿O que colocase ramas verdes sobre la
tumba de su difunto esposo? (Ashur, 2008:152)

Pero, cuando Naím le cuenta la historia de "Juana la Loca", esto la ayuda en entender: “... aquellas leyes extrañas e injustas fueron producto de una mente desquiciada" (Ashur, 2008:152) Por eso notamos la utilización de adjetivos como "locos y perturbados", más de una vez, para describir a los castellanos, como si es una afirmación que quien rechaza al otro debe ser "loco".

\section{- La función justificadora}

Paul Ricoeur no puede entender cómo nace una imagen falsa de la realidad. Así, nos dirigimos a un segundo nivel, en el cual, la ideología parece menos parasitaria y falsificadora que justificadora. Marx mismo se acercó en este sentido al declarar que las ideas de la clase dominante se convierten en ideas opresoras, haciéndose pasar por ideas universales. De ese modo, los propios intereses particulares de una clase particular se convierten en universales. 
Marx ha tocado aquí un fenómeno más interesante que la mera noción de inversión y disimulo, a saber, la tentativa de justificación que acompaña el fenómeno mismo de la dominación. Ricoeur acepta este pensamiento de Marx, como una de las consecuencias de la sociedad de clases, como la resultante de la explotación que llevan a cabo las clases dominantes. Toda dominación trata de justificarse y lo hace recurriendo a nociones capaces de aparecer como universales, es decir, válidas para todos nosotros. Marx afirma en sus escritos que las ideas de la clase dominante, si fueran solamente eso, aparecerían ante el conjunto social como un sistema de ideas de un grupo y por lo tanto extrañas a la totalidad del sistema social. Necesitan convertirse en "ideas universales", válidas y legítimas para toda la sociedad para que puedan, efectivamente, ejercer su dominio. Ahora bien, existe una función del lenguaje que responde a esta exigencia. Platón es, sin duda, el primero que subrayó que no existe la tiranía sin la ayuda de un sofista. La fuerza bruta no triunfa sin un ejercicio de persuasión confiado a sofistas públicos.

En otras palabras, J.A. Hobson explica que las fuerzas egoístas que dirigen, en nuestro caso, el Imperio castellano, en su tarea de reforzar su identidad y el consenso de sus sociedades sobre las atrocidades que comete contra el otro, deben utilizar los colores protectores de los movimientos desinteresados, tales como la filantropía, la religión, la ciencia y el arte. (Said, 1996:48) Esto es exactamente el oficio del padre Miguel, el señor de Naim. Miguel siempre está escribiendo, y cuando Naim le pregunta qué está escribiendo le contesta que está documentando la historia de Cristóbal Colon, el descubrimiento de América, la descripción de la isla donde viven y de sus habitantes, sus apariencias, sus modo de vida y sus ideas y creencias. Para Naim el objetivo de Cristóbal Colon al empezar la aventura de viajar al nuevo mundo es descubrir nuevos territorios desconocidos y ricos en oro y plata. Pero al contrario el clérigo le dice que el verdadero objetivo es:

\footnotetext{
“... un sueño sublime y noble... divulgar la palabra de Dios entre aquellos a lo que aún no les ha llegado, acogiéndolos al seno de la iglesia, y
}

conseguir oro para organizar una cruzada hacia los Santos Lugares que conquiste Jerusalén y rescate la tumba de Jesucristo de quienes reniegan de Él". Pero cuando Naim le dice que los musulmanes no niegan a Jesucristo, le lanza una mirada fulminante y afirma: "Sí que reniegan". (Ashur, 2008:209)

Así, el padre Miguel, el misionero es capaz de atenuar los peores excesos coloniales, justificando el imperialismo castellano, dándolo una cubierta religiosa. Cuando Naim le pregunta si va a contar las atrocidades que cometen los castellanos contra los indígenas, le contesta que ciertamente lo va a hacer. Sí, se cometen "dolorosas cuestiones" (Ashur, 2008:209), pero el alto objetivo del proceso imperial es más importante. Esta es la fuerza de la idea. Es una de las características de la ideología, es decir, oscurecer la fea verdad bajo un régimen de justificaciones. Edward Said (1996:125) ratifica esta opinión al citar a Joseph Conrad:

\footnotetext{
... La conquista de la tierra, que mayormente quiere decir quitársela a otros que tienen diferente complexión o una nariz ligeramente más chata que la nuestra, no es una cosa muy agradable si se la mira demasiado de cerca. Lo único que la redime es la idea. Que haya una idea en su fondo, y creer generosamente en la idea: algo que se pueda erigir, ante lo cual posternarse, ante lo cual ofrecer un sacrificio....
}

Así el castellano consigue construir su imagen como "hombre religioso y civilizado", cuyo objetivo es llevar luz a los lugares oscuros. Casi todos los proyectos coloniales empiezan con la suposición del atraso del nativo, de su imposibilidad general para ser independiente e igual. Aunque, el padre Miguel está estudiando la cultura de la gente de la isla conquistada para, aparentemente, aprehenderla, en realidad lo hace para encontrar la mejor manera de controlarlos. El padre Miguel escribe para extraer lo que considera una evidencia directa, es decir, la existencia de nativos, que son especies inferiores, son esclavos que practican la magia negra para dañar a los castellanos. Y ciertamente el objetivo es asegurar la superioridad de la raza castellana blanca de indiscutida autoridad.

Sastre era capaz de afirmar, en las primeras líneas de su prólogo a "Los condenados 
de la tierra", que el mundo está realmente compuesto por dos bandos opuestos: "Quinientos millones de hombres y mil quinientos millones de nativos. Los primeros poseen la Palabra; los otros su uso... En las colonias la verdad se yergue desnuda, pero los ciudadanos de la madre patria la prefieren vestida". (Said, 1996:306) Este es el mismo ideal que refleja la "Trilogía": la contradicción entre los castellanos y los nativos. Según la imagen ideológica de los castellanos, los nativos son brutos, esclavos, brujos que no merecen el trato humano. Mientras que la "Praxis" es que "los castellanos estaban matando a su pueblo y profanando la honra de sus mujeres sin piedad". (Ashur, 2008:246). Pues, la "Trilogía" invierte el paradigma según el cual España había dado a las colonias su modernidad, y afirma al revés que el bienestar y el progreso de España se sustentó en el sudor y la agonía de los nativos. El castellano sólo ha sido capaz de convertirse en hombre creando esclavos y monstruos. Esto es el caso de la fracasada historia de amor de Naim y Maya. Naim ha pasado mucho tiempo buscando el verdadero amor, y lo encuentra en Maya, quien simboliza para él su madre patria con todo su sufrimiento. Los dos huyen y se casan contra las leyes de los castellanos. Cuando se enteran de que Maya está embarazada, Naim elige los siguientes nombres para los niños: "Badr" (luna llena), "Hilal" (luna creciente) y "Qamar" (luna). Son las tres fases lunares. Es siempre la luna que disipa la oscuridad de la noche. Para Naim, la luna es la única esperanza de que el sol reaparezca otra vez. El embrión que se está gestando dentro de Maya simboliza la única luz que ilumina el mundo oscuro, injusto, y es la esperanza en un futuro mejor. Sin embargo, el castellano rechaza cualquier acción en contra de su indiscutida voluntad, y ciertamente niega a Naim cualquiera esperanza, por eso lo persigue y mata a Maya y su feto. Así, el castellano convierte a Naim en un viejo, loco y desesperado monstruo, sin futuro.

La contradicción entre la actitud de los castellanos y la de los granadinos hacia el sufrimiento de los nativos es muy clara, especialmente por las comparaciones que hace la autora a lo largo de la novela. Por ejemplo, la comparación entre la actitud de Naím y la de los soldados castellanos hacia la desnudez de las mujeres nativas. Los soldados, al violarlas, están descritos como los perros que "acosaban sus presas hasta poseerlas, rasgar la carne y penetrarla", y al contrario, Naím "pasaba y bajaba la vista como si aquellas mujeres fueran de su familia y le fuera imposible transgredir esa barrera sagrada fijándose en ellas". (Ashur, 2008:206) Pero, ¿cuál es la relación entre la conquista y la violación de las nativas? Edward Said responde a esta pregunta explicando la existencia de un lazo entre poder y placer. Es decir, el militar añade al placer de la vigilancia y gobierno del lugar, un placer sensual y cruel. La desnudez de las nativas es solamente un estilo de ropa o de vida diferente al del castellano. Sin embargo, la visión ideológica del militar castellano, quien rechaza al otro con su diferencia, la explica como erotismo femenino, que articula relación de poder y revela el deseo de realizar la supremacía a través de su abuso. Otra vez utiliza la ideología para justificar sus acciones.

Sin embargo, la "Trilogía" no favorece los estereotipos negativos. Por eso, entre los soldados castellanos que disfrutan mirando cómo un perro devora un bebé mientras su madre grita, aparece uno que "contemplaba la escena, y moviendo su cabeza mecánicamente" (Ashur, 2008:205) La monstruosidad de la escena le chocó. Asimismo, el padre Miguel, una noche se queda rezando y sollozando después de haber visto los cuerpos de diez mujeres nativas tambaleando en las cuerdas de la horca, mientras que sus niños están colgados de sus pies. Pero la autora no nos dice por qué está llorando el padre Miguel: ¿está pidiendo perdón de Dios? ¿Siente remordimiento por ser, de una manera $\mathrm{u}$ otra, parte de este grotesco proceso imperial? ¿Por ser incapaz de imponer tales atrocidades? Todo esto puede ser, pero lo único cierto es que el sufrimiento del autoritarismo del otro, sea en Granada o en el Nuevo Mundo, une a Naím y los nativos.

A pesar de todas las leyes injustas y crueles del castellano, los moriscos hacen que cualquier modificación sea imposible, 
lo que provoca la frustración y la ira de los gobernadores y la consecuente necesidad de la violencia a través de la inquisición y los autos de fe. Así llegamos a la segunda figura castellana representada por la autora en esta novela, que es el inquisidor. Radwa Ashur nos presenta tres inquisidores que investigan las acusaciones contra Salima, la nieta de Abu Yáfar: Antonio Agapida, Alonso Madera y Miguel Aguilar. El nombre del primer juez es muy interesante, ya que coincide con el del fray Antonio Agapida que es "uno de los muchos autores españoles infatigables que llenaban las bibliotecas de los conventos con sus obras. Su ardiente celo, también, en la causa de la fe católica, le da derecho a ser presentado como un modelo de los viejos cronistas ortodoxos, que grabaron con tal exaltación piadosa los triunfos unidos de la cruz y la espada." (Irving, 1838:10) Basta mencionar aquí cómo fray Agapida describe la Reconquista de Granada como una "cruzada piadosa, llevada a cabo por la mayoría de los soberanos católicos, para rescatar del poder de los infieles una de las regiones más hermosas, pero ignorante del mundo". (Irving, 1838:13)

La labor de los inquisidores se centra en demostrar la imagen diabólica de los supuestos enemigos de la fe católica. Para llevar a cabo esta labor necesitan acusaciones graves que justifiquen las crueles condenas que van desde prisión, hasta la azotaina y la hoguera. En el caso de Salima los inquisidores la acusan de brujería y basan sus acusaciones sobre los testimonios de algunos vecinos vengativos de Salima. La autora aquí nos representa la lógica y la prudencia de Salima en contra de las supersticiones, la ignorancia y el fanatismo de los inquisidores. Tras jurar sobre la Biblia que dirá la verdad, comienza el interrogatorio, en el que todo lo que ella dice, cargado de lógica, será distorsionado por el Tribunal del Santo Oficio para que sirva de confirmación a sus acusaciones. La primera prueba será que había tenido una hija con el diablo, la segunda su trato con el diablo, y la tercera la apostasía.

Una vez acusada, a Salima no le quedan posibilidades de sobrevivir. Los jueces la someten a tormento e interrogatorios, hasta que confiesa lo que ellos quieren oír: que ha hecho pacto con el diablo y que ha tenido relaciones sexuales con él. Los elementos eróticos y misóginos eran fuertes como puede esperarse de una sociedad reprimida sexualmente, dominada por varones, con inquisidores procedentes de la Iglesia, nominalmente célibes.

\begin{abstract}
Antes de que la condujeran ante aquellos tres inquisidores, la llevaron a una mujer como un gigante, corpulenta y severa, que le cortó el pelo y le ordenó quitarse la ropa, toda, hasta quedar desnuda como su madre la trajo al mundo. Después la mujer comenzó a inspeccionaría palpándola bajo las axilas, entre los muslos, en los orificios de la nariz, en la boca y en las orejas, en la vagina y en el ano. Pero ¿qué estaba buscando? ¿Se trataba de una broma? ¿De una locura?" (Ashur, 2008:276). Lo que Salima no sabe, es que sus inquisidores creen que las "marcas del diablo se encontraban generalmente en los pechos o partes íntimas. (Maza)
\end{abstract}

Los inquisidores manejan el juego ideológico de cambiar las verdades e interpretar las palabras de Salima de tal forma que corrobore sus sospechas: el dibujo que Salima ha hecho de su querida gacela, es "¡un macho cabrío, no una gacela! (...). Si, el macho cabrío que hizo que tu marido se fuera y te abandonara... ¡Es Satán, aquel para el que tú trabajas!” (Ashur, 2008:275). Las semillas, hierbas y pócimas con las que prepara remedios para curar a los enfermos, se transforman en componentes que Satanás le ha enseñado a fabricar para practicar la magia negra contra los inocentes castellanos. Negar su creencia en el demonio y contar la historia de la bestia alada que transportó a Mahoma desde La Meca a Jerusalén, estas dos confesiones son suficientes para que Salima sea acusada de apostasía. Cuando los inquisidores necesitaran buscar más pruebas, deciden nuevos interrogatorios y tormentos para Salima. Pero otra vez, el hecho de que Salima superara la dura prueba de agarrar la barra de hierro al rojo con las manos y dar pasos firmes, no significa, para los inquisidores, su inocencia. Al contrario, afianza su convencimiento de que se está apoyando en las fuerzas sobrenaturales de Satán, que la hacen capaz de soportar tal dolor.

Durante las largas deliberaciones, los inquisidores recurren a retorcidos argumentos 
teológicos para justificar el delito a partir de las respuestas de Salima. Tales deliberaciones reflejan el fanatismo de los inquisidores. Hasta el punto que uno de ellos solicita la pena de muerte para Aixa, la niña de Salima por considerarla la hija de Satán. Cabe mencionar aquí también la felicidad y alivio que siente Alonso Madera, el joven inquisidor, al probar la apostasía de Salima, lo que hace que sea llevada a la hoguera. Cada vez que logran, desde su punto de vista, confirmar una acusación contra Salima: "Los inquisidores volvieron a intercambiar la misma mirada, esta vez con un brillo añadido en los ojos del joven inquisidor que se sentaba a la derecha del juez" (Ashur, 2008:280)

\section{- La función integradora}

Después de cumplir con las dos funciones de la ideología, que son la falsificación y la justificación, viene la tercera y última función, que es la integración. (López: 2007)) Esta función reactualiza, de alguna manera, los acontecimientos que considera como fundamentales de su propia identidad: es, en consecuencia, una estructura simbólica de la memoria social. En nuestro caso, los autos de fe cumplen con esta función perfectamente. Los autos de fe son públicos y se celebran a las puertas de las iglesias en medio de una muchedumbre expectante: "Multitudes castellanas llegan a participar en la celebración, contemplando sus interesantes detalles." (Ashur, 2008:187) En tales autos se escucha "la lectura del responsable de exponer los cargos y sentencias, que saltaba de nombre en nombre y de sentencia en sentencia hasta terminar." (Ashur, 2008:185)

En este sentido, la tortura física no tiene solamente el objetivo de forzar al acusado para confesar su delito. Los signos de la tortura representan una "organizada codificación sobre el cuerpo del acusado, para que sean vistos por las multitudes congregadas". (Foucault, 1979: 33) Así, el pueblo acude a tales celebraciones para escuchar las acusaciones contra los moriscos y atestiguar las condenas. Para los castellanos que se reúnen allí, los autos de fe son las ocasiones idóneas para alimentar su odio hacia el otro mediante acusaciones sobre brujería, traición, apostasía, ateísmo... etc. En este sentido la ideología sirve de relevo a la memoria colectiva, a fin de que el valor inaugural de los acontecimientos fundadores se convierta en objeto de creencia de todo el grupo.

\section{- Nacionalismo y fanatismo}

El nacionalismo, que es la restauración de la comunidad, afirmación de la identidad, emergencia de nuevas prácticas culturales, instiga y propulsa la resistencia. En el caso de $\mathrm{Al}$ andaluz, tal resistencia tiene muchas formas: las rebeliones armadas, la holgazanería, y el esfuerzo cultural por el rechazo. Según Edward Said (1996:326), la principal enseñanza del nacionalismo es la necesidad de encontrar una base ideológica que sirviera de sustento a una unidad más amplia que la conocida hasta aquel momento. Pero lamentablemente, el nacionalismo refuerza la distinción, y en este caso se convierte en tribalismo fanático. Es decir, como lo explica Edward Said (1996:339), cada grupo se une reivindicando tanto la independencia como el nacionalismo, basándose en un sentido de identidad étnico, religioso o comunitario opuesto a cualquier tipo de futura opresión. Y esto es el error que cometen tanto los castellanos como los moriscos. A lo largo de la novela, todos los intentos de construir un modelo de orden armonioso, fracasan ya que las potencias actúan guiadas por la percepción agresiva de intereses nacionales o soberanías ilimitadas. Esto es lo que Edward Said (1996:58) llama un "tribalismo nuevo", que fractura sociedades, separa pueblos, promueve conflictos mezquinos y sangrientos y se sustenta en afirmaciones de minorías étnicas o particularidades grupales muy poco estimulantes.

Como hemos explicado antes, los castellanos deciden rechazar cualquier acción que contradice su tradición castellana. Por su parte, algunos de los moriscos eligen la soledad, como una afirmación de su resistencia hacia lo que perciben como trato injusto hacia ellos. Esto es el caso de la familia de "Banu Tuhama" que se aísla en sí misma rechazando mezclarse 
con los demás árabes del pueblo donde viven y jamás se casan con muchachas que no fueran de los suyos. Su tribalismo fanático se refleja en injustas prácticas machistas contra las mujeres de la familia: los crímenes de honor. Salsabil y su hermana gemela Cáuzar son asesinadas por su padre y hermano por enamorarse de dos jóvenes extranjeros, lo que contradice las tradiciones de su familia. Pero el caso de Cáuzar es más interesante ya que lo que aumenta más el conflicto es su problema de identidad. Cáuzar rechaza la brutalidad cometida contra su hermana, huye de la casa de su familia, y para colmo se casa con un joven castellano. Cuando Alí le pregunta cómo ha podido casarse con un cristiano, le contesta: "¿Acaso no lo somos ya también nosotros?”. (Ashur, 2008:502).

Alí, aunque rechaza lo que ha hecho Cáuzar, también rechaza la violencia y el aislamiento y decide mantener una buena relación con su viudo, Sancho López, y su hija. Alí está buscando "un lugar donde la gente vive hombro con hombro armónicamente". Pero no son Mariama y Ali solamente quienes creen y sueñan con la utopía, sino todas las clases marginadas, con independencia de su religión, su color o su raza. Como la "Trilogía" rechaza los estereotipos, por eso, representa otras voces no-árabes que rechazan el odio y las luchas, como las dos mujeres que salvan a "Nayat" de la inquisición. Nayat y las demás mujeres son prostitutas, una de las clases marginadas, que según las palabras de una de ellas, aguantan tanta humillación, que debería volverse locas. En una pelea entre Nayat y otra prostituta que según su descripción debe ser castellana (una mujer de mediana edad con una melena pelirroja espesa cayéndole sobre los hombros). Ésta insulta a todos los árabes (perros, hijos de esclavos, además de bastardos) y al profeta de los musulmanes. Nayat que rechaza la humillación le dice que “... este zapato mío tiene más honra que tú, que el gran cardenal y que el rey que manda en esta tierra". La autora solamente se limita a decir que dos mujeres defienden a Nayat, y que la primera es "madura, morena y gorda", y la segunda es "otra mujer" que dice simples palabras, pero en resumen el mensaje de la autora se centra en:
“AA qué viene tanta riña? Si al final todos nos vamos a morir y nos iremos al cielo con Dios, que buena misericordia tendrá de nosotros por lo que llevamos penado en este mundo". (Ashur, 2008:485) Todos están en espera de la utopía. Pero es cierto que está en otro lugar más lejos.

\subsubsection{Utopía}

Si la ideología refuerza, redobla, preserva $y$, en este sentido, conserva al grupo social tal cual es, la función de la utopía es, entonces, la de proyectar la imaginación fuera de lo real. He ahí el primer sentido de la palabra utopía: un lugar que es otro lugar, una otra parte que es ninguna parte. Aquí habría que hablar no sólo de utopía, sino también de ucronía, a fin de subrayar no sólo la exterioridad espacial de la utopía (otro lugar) sino también su exterioridad temporal (otro tiempo). (López: 2007) Si la ideología preserva y conserva la realidad, la utopía esencialmente la cuestiona. En ese sentido, la utopía es la expresión de todas las potencialidades de un grupo, que se encuentran reprimidas por el orden existente. La utopía es un ejercicio de la imaginación para pensar un "otro modo que ser" de lo social. Por su parte, Moura concibe la utopía como "una función de la subversión social". (Romero, 2005:14)

En vez de terminar la novela con la escena de la muerte de Salima en la hoguera, que ya la ha anticipado cuando Salima se la imaginaba a solas en la celda, la autora prefiere cerrar la primera novela de la Trilogía con un cuento que Mariama cuenta a Aixa, o Esperanza como su tío Hasan suele llamar a la hija de Salima, para superar su dolor y entretener a la niña:

En el cielo, Aixa, hay un árbol grande con tantas hojas verdes como gente hay en la tierra. Toda la gente de la tierra: chicos y grandes, niños y niñas, los que hablan arábigo como nosotros y los que no lo hablan. Un árbol grande, Aixa, al que se le caen hojas y le crecen hojas sin parar. Y cada año en la Noche del Destino, el árbol florece con una flor extraña y maravillosa. Y aquel año en que ocurrió la historia, el árbol dio una flor.... (Ashur, 2008:289)

Mariama siempre huye de la dolorosa realidad hacia la utopía utilizando el humor, los 
cuentos excéntricos y los sueños de la vuelta de los queridos. Los cuentos de Mariama, casi siempre religiosos, la elevan a un plano extramundano utópico por encima de lo terrenal ideológico. Mariama conserva su cultura manteniendo viva su conciencia de las cuestiones metafísicas. Este cuento cargado de esperanza, refleja uno de los temas principales de la novela, que es la posibilidad de comunicarse con el otro en términos de paridad y convivencia pacífica. En la tradición islámica, Mahoma ve una escalera que sube del templo de Jerusalén hasta el cielo, con ángeles a derecha e izquierda; por esa escalera subían las almas de los justos hacia Dios. Según Mircea Eliade (1981:277), en todas las tradiciones religiosas y en todos los éxtasis místicos se incluye una subida al cielo. La subida de montañas o escaleras, o bien, subir volando por la atmósfera, etc., significan siempre trascender la condición humana $\mathrm{y}$ penetrar en niveles cósmicos superiores. El mero hecho de la "levitación" equivale a una consagración y a una divinización. En otros términos, llegar a la utopía.

Mariama, que es una andaluza y musulmana perseguida por el otro que está en el poder, describe en este cuento la utopía, pero lo más interesante es que ella, no se imagina a sí misma sola allí, sino que está acompañada de su perseguidor. Sin embargo, en la utopía los dos son iguales. Radwa Ashur rechaza quedar atrapada en la indulgencia emocional de la celebración de la propia identidad. Incluso afirma la posibilidad de descubrir un mundo que no esté construido sobre esencias opuestas, sino un universalismo que no sea limitado ni coactivo.

El mundo es como un árbol grande, y los hombres son sus hojas. Mircea Eliade (1981:278) ha estudiado con detenimiento las múltiples interpretaciones del árbol, subrayando que posee un poder especial, no solo como teofanía (Atis, Osiris o Artemis), sino también como símbolo del universo: "El árbol puede, sin duda, llegar a ser un símbolo del universo, y bajo esa forma lo encontramos en las civilizaciones más avanzadas, pero para una conciencia religiosa arcaica, el árbol es el universo, y es el universo porque lo repite y lo resume a la vez que lo "simboliza." Además añade que en el árbol se reúnen los cuatro, esenciales y opuestos, elementos de la vida: el agua, el aire, la tierra y el fuego. Sin la armonía entre los cuatro elementos, el universo perderá su equilibrio. Asimismo, sin la armonía entre los hombres de diferentes religiones, diferentes colores y diferentes etnias, prevalecerán el odio, la persecución y las guerras en el mundo.

De esta manera, la utopía significa la aculturación, la aceptación del otro como está, sin intentar cambiarlo por la fuerza. La relación entre Alí y Antonio es la mejor prueba de esto. Alí y Antonio son muy buenos amigos, pero Alí es rechazado totalmente por parte del padre de Antonio quien lo maltrata y lo rocía con agua. Pero esto no afecta la amistad entre los dos niños, cuya inocente mentalidad no puede aceptar ni justificar la desigualdad y la injusticia basada en el color, raza o religión: "El padre de Antonio, es como es, y no está en nuestra mano cambiarlo, ni siquiera en la suya" afirma Alí. (Ashur, 2008:379) Dicha amistad fuerte y estrecha, que crece con los niños y permanece a lo largo de los años, explica las lágrimas de Antonio a la hora de despedir a su amigo, expulsado de Granada con los demás árabes por orden del rey. Además, Antonio le regala la única cosa preciosa que tiene, cuya madre se lo había dado cuando era niño, un pendiente de oro con una cruz, un símbolo de la compasión y la aculturación.

Además, podemos añadir que la mezcla entre la tragedia y el humor y la ironía, es una manera de generar energía y optimismo de victoria contra las campañas represivas de los castellanos. Por ejemplo encontramos a los niños en sus juegos, conmovidos por los cuentos heroicos que escuchan de sus padres sobre Hamed El Zegrí, en los que se representa a éste como un gran rey, mientras, de una manera humorística, se burlan de la injusticia y arrogancia de los soldados castellanos. Otro caso es la ironía que muestra Mariama hablando con el profesor de la escuela misionaria. Mariama para negar el delito de la circuncisión y huir de la inquisición, engaña al profesor convenciéndole que "Igual que la piel de ustedes tira a blanca y la nuestra a morena, sus niños nacen con ese añadido y los nuestros 
nacen sin él... por desgracia". (Ashur, 2008:179) Tal humor tiene la fuerza utópica del "mundo al revés", en que las carcajadas de los moriscos a la necedad de los castellanos, convierten al débil en fuerte forjando su confianza en sí mismo.

Asimismo, el libro se convierte con esta novela en un icono de la liberación de la ignorancia, el subdesarrollo y la opresión. Esto aparece claramente en la relación entre Salima y los libros. No es simplemente una relación cognitiva, sino existencialista. Salima huye de su vida cotidiana con la ayuda de los libros hacia su utopía. Ansiosamente, cada día espera la llegada de la noche para quedarse sola con sus libros, pero "la luz del sol que brilla de los libros" vence la oscuridad del mundo real ignorante e injusto.

\section{El "Yo" mediante el "Otro"}

\begin{abstract}
No se había caído aún, pero se le doblaban las patas delanteras. De un orificio color púrpura que tenía en el pecho le mandaba un hilillo de sangre. Estaba rodeado por las puntas de las lanzas que esgrimían los cazadores, en cuyos ojos brillaba salvaje el orgullo por la pieza lograda. Iban tocados de sombreros con plumas de avestruz y vestidos con trajes de terciopelo bordado y calzas de seda ajustadas a las piernas musculosas, recias. Todos era de colores: los sombreros, sus plumas, los ropajes, las cornetas que tocaban los monteros, los galgos jadeantes, con la lengua fuera tras la larga persecución; los árboles: naranjos, cerezos y granados; y las flores: violetas, azucenas, narcisos y rosas". "El venado inclinaba la testuz como si le pesara la corona de cornamenta enmarañada. Parecía mirar triste al vacío. Más allá de la pena, la dulzura confería a su rostro rasgos humanos. (Ashur, 2008: 336)
\end{abstract}

Este es un cuadro que Mariama vio en la casa de doña Blanca, la mujer de don Pedro que trabajaba en la chancillería. La elección del venado es muy interesante. En la antigüedad, los árabes relacionaban entre los cuernos de los animales y la luna creciente, que simbolizaba la fertilidad, por eso santificaban todos los animales con cuernos. En la lengua árabe, el nombre del "venado" tiene muchas connotaciones, entre ellas, la montaña y el gran señor, la masculinidad y la fertilidad, la grandeza y la altura, la resistencia y la fuerza.
De todas estas características, se destaca la supremacía del venado sobre los demás animales con cuernos, especialmente por la longitud de los suyos. Además, según el diccionario de Cirlot, la cacería "podría tener un significado general de búsqueda general muy apasionada, pero más bien se relaciona con la idea de hacer presa e incluso víctima. En Ramacaritamanas, de Tulsidas, autor de la India del siglo XVI, hay una cacería de un ciervo de oro, que parece resonancia del de la leyenda del rey Arturo, pero que puede ser un paralelismo nacido de idéntico simbolismo". (Cirlot: 2006, 120) La autora eligió este animal raro y superior como símbolo de "Al Ándalus" que también representa un caso raro en la historia mundial. Una comunidad única donde convivían diferentes étnicas, culturas y religiones, creando una sociedad civilizada y moderna (según los criterios de aquella época), y que era un modelo a seguir para toda Europa. Asimismo, el venado es un símbolo de los moriscos, que cada día reciben un nuevo dictado, como las lanzas que esgrimían los cazadores. Las lanzas se dirigen al pecho del venado, y los dictados se dirigen al corazón del morisco. Las lanzas quitan la vida del venado, mientras que los dictados arrebatan la cultura, la religión, la identidad y la vida del morisco. Sin embargo, el venado está herido mortalmente, pero niega caer. Exactamente como los moriscos, indefensos e impotentes, pero todavía la mayoría de ellos niegan someterse, y eligen la resistencia, sea la lucha armada y las rebeliones o la disimulación.

Cabe mencionar aquí también que el venado no es solamente símbolo del morisco de aquella época crítica de la historia. Según Radwa Ashur, "el autor ve en la inscripción de Granada, el reflejo de su tiempo". Así podemos además añadir que el venado herido representa toda la generación de la autora de la trilogía. Una generación que experimentó muchas derrotas y depresiones. Una generación que soñaba con la "liberación nacional árabe", pero tal sueño recibió muchos ataques por parte de la nueva potencia principal. La autora y toda su generación son como los moriscos, es decir, árabes derrotados y arrojados a la parte inferior de las escalas 
económicas y sociales, perdiendo su verdadera identidad, pero siguen resistiendo.

Frente a la tristeza del herido venado, aparecen "los cazadores, en cuyos ojos brillaba salvaje el orgullo por la pieza lograda". Aquí, los cazadores son símbolo de los castellanos que piensan que ya han sitiado y derrotado al otro, es decir a los moriscos, que amenazan su identidad y su unidad. El sitio del animal aquí tiene un sentido simbólico que es que la exclusión forzada y el exorcismo de lo otro es un acto de formación de la propia identidad. Además, la descripción lujosa del ropaje de los cazadores, refleja la contradicción entre las apariencias y la realidad. El orgullo (por conseguir un animal tan raro y fuerte) y la elegancia de los cazadores contradice con el acto salvaje de matar un animal indefenso. La autora y su generación se identifican con el venado y los cazadores con la nueva potencia principal mundial. Ésta aparece frente a todo el mundo como el estado más civilizado y avanzado, mientras que, en la conciencia colectiva árabe, está cometiendo tantas atrocidades como negar a otras naciones su derecho de autodeterminación y atacar sus culturas e identidades. La autora tiene los mismos sentimientos del venado: pena y tristeza por las derrotas del pasado y el presente, y miedo del futuro.

La autora al empezar escribiendo su novela, después de ver en la televisión el bombardeo estadounidense del Iraq, tuvo en cuenta una pregunta urgente: “¿es este el final?". Tal pregunta nacida de sus sentimientos de impotencia y miedo y con una conciencia sobre una historia amenazada. Radwa Ashur quería crear una novela sobre la desesperación, los finales y la muerte, sobre una minoría menospreciada por los que están en el poder, con una identidad confundida y al punto de la perdición. Es el mismo caso del venado herido de la pintura, que está a punto de caer y ya no puede más llevar su "corona de cornamenta enmarañada", en un símbolo de la aproximación del final. Cabe mencionar aquí "el sentido simbólico del venado que lo liga al Árbol de la Vida, por la semejanza de su cornamenta con las ramas arbóreas. También es símbolo de la renovación y crecimiento cíclicos" (Cirlot: 2006, 135).

Sin embargo, el final de la novela contradice con el objetivo inicial de la autora.

.... Se quedó dormido, y en sueños, se vio a sí mismo bajar como si la tierra tuviera siete niveles, igual que el cielo. Y llegó hasta una caverna amplísima...... En el otro lado vio un lecho alto, de mármol. Se acercó a él. ¡Moraima! Yacía inerte sobre él, su cuerpo era de madera oscura, su rostro sonreía. Sobre su pecho gorjeaba un ave ganga, y en los pies había granos de trigo sobre los que volaban más pájaros. Se acercaban a cogerlos, alzaban las cabezas, picaban, batían las alas y echaban a volar. Ruiseñores, alondras, jilgueros, tórtolas y alcaravanes. (Ashur. 2008: 568).

Es la tumba de Mariama, pero está llena con vida. Ali, quien se dirigía al puerto después de ser expulsado en 1609, de repente dio la espalda al mar y decidió volver a su tierra para vivir junto a la tumba de su abuela, donde "no habrá desamparo", y donde están también escondidos los últimos libros árabes que fueron salvados de la hoguera de la inquisición. Así, la trilogía no es una novela patética sobre la muerte y la perdición. "Granada" es la vida, o como Radwa Ashur misma la describe, "es una huerta llena con significados ocultos en el adentro de la tierra”. Según la autora, esta descripción está inspirada en las tumbas faraónicas de la Valle de los Reyes en Luxor. Así podemos decir que, en la historia árabe, Granada es como las tumbas faraónicas donde están enterrados los reyes del Antiguo Egipto, y con ellos todos los secretos de la vida y su grandeza.

\section{Conclusión}

Muchas son las obras literarias árabes, tanto modernas como antiguas, que tratan la historia de "Al Ándalus", en un intento de comparar el pasado y el presente. El tema de la Reconquista de Granada y la decadencia de la cultura andaluza es una alegoría que refleja la decadencia de la cultura árabe en la era de la globalización y la exclusión de los árabes del círculo de la historia de la civilización. La trama 
de "Granada [Trilogía]" se basa en la binaria opresión y resistencia, con una visión hacia el futuro que impulsa la resistencia en el presente. Pues, la historia no es solamente un pasado, sino que además son elementos activos e interactivos que forman el presente cotidiano.

Finalmente podemos concluir que Radwa Ashur en esta obra trata el tema de la leyenda negra española, un tema examinado por muchos autores de diferentes nacionalidades, y en particular la inquisición, la conversión forzada, la expulsión...etc. Sin embargo, nuestra autora, sí está interesada por la historia de Al Ándalus, pero en esta obra analizada aprovecha el tema histórico para representar el imagotipo, no solamente del español, sino de todos los imperialistas, tratando su autoridad, crueldad, intolerancia, fanatismo, orgullo, desprecio y el odio al otro. Además, según el punto de vista de la autora, todos estos hechos conducen a la estupidez y la locura.

Del mismo modo, Radwa Ashur en esta novela representa el "yo" mediante el "otro". Es decir, la autora al pintar el heteroimagotipo del español, que es en este caso un símbolo del imperialista occidental, pinta el autoimagotipo del morisco perseguido y aniquilado, que es por su parte, un símbolo de todas las víctimas del imperialismo occidental. La autora empieza planeando el caso particular de los moriscos de Granada y Al Ándalus, para pasar después al caso general, o mejor dicho, universal, tratando el sufrimiento de los nativos del nuevo mundo y de los egipcios maltratados por los mamelucos. El imperialismo no tiene nacionalidad ni religión.

Junto al estereotipo reproductivo del imperialista y su relación con sus súbditos, que es un reflejo del estereotipo colectivo, nuestra autora representa otro estereotipo productivo, una nueva creación, una innovación de su fuerza creativa que se distancia de las imágenes sociales colectivas: la vida en Jerusalén y la convivencia entre los musulmanes y los cristianos. El objetivo principal de la autora es luchar y denunciar el plan occidental de las grandes fuerzas mundiales de subordinar al resto del mundo, mediante la anulación de su propia identidad. Pero Radwa Ashur, no solamente critica al "otro", sino que también representa una autocrítica del nacionalismo, cuyo exceso puede conducir a un fanatismo mortal. Para nuestra autora, la relación entre el "otro" y el "yo" no debe ser una relación autoritaria, sino dialógica. O como lo expresa Amin Maalouf (2010: 244) “..., para promover la diversidad, el camino es el reconocimiento por parte de cada persona y cada sociedad de su propia diversidad, y no la defensa agresiva de las identidades tribales".

\section{Bibliografía}

Abiada, José Manuel López de. 2004. Imágenes de España en culturas y literaturas europeas (Siglos XVI-XVII). Madrid: Verbum.

Ashur, Radwa. 2000. "Cada uno tiene su propia Granada". En Radwa Ashur. Disponible en $<$ http://www.radwaashour.net/ar/?page $\mathrm{id}=721>$ [Consulta: 12 de Marzo de 2013].

.2008. Granada [trilogía]. (María Luz Comendador [trad.]). Madrid: Ediciones del Oriente y del Mediterráneo.

Castro, Fátima Roldán e Isabel Hervás Jávega. 2001. El saber en Al-Andalus (textos y estudios). Sevilla: Universidad de Sevilla y Fundación El Monte.

Cirlot, Juan Eduardo. 2006. Diccionario de símbolos. Madrid: Siruela.

Dijk, Teun A. Van 2006. "Ideology and discourse analysis". En Journal of Political Ideologies. 11 (2): 115-140.

Foucault, Michel. 1979. Discipline and punish: The birth of the prison. (Alan Sheridan [trad.]). New York: Vintage.

Irving, Washington. 2006. A chronicle of the conquest of Granada / by Fray Antonio 
Agapida. Disponible en < http://books. google.ie/books/about/A_chronicle of_the_conquest_of_Granada_f. html?id=U0YAxgLuybsC $>$ [Consulta: 6 de Mayo de 2013].

Kramer, Heinrich y Jacobus Sprenger. Malleus Maleficarum (El martillo de los brujos). (Floreal Maza [trad.]). Disponible en $<$ http://www.gabrielbernat.es/espana/ inquisicion/Malleus_Maleficarum.pdf> [Consulta: 15 de Mayo de 2013].

Leerssen, Joep. 2007. "Imagology: History and Method". En Manfred Beller y Leerssen (eds.) Imagology. The Cultural Construction and Literary Representation of National Characters. New York, Rodopi. pp. 17-32.

López, Ricardo Vicente. 2007. "Ideología y utopía". En Cuadernos de reflexión. Disponible en $<$ http://www. ricardovicentelopez.com.ar/> [Consulta: 20 de Enero de 2013].

Maalouf, Amin. 2010. "Los retos de la interculturalidad en el Mediterráneo", en Quaderns de la Mediterrània. 14: 244-249.

Mircea, Eliade. 1981. Tratado de historia de las religiones. Morfología y dinámica de lo sagrado. Madrid: Ediciones Cristiandad.

Moll, Nora. 2002. "Imágenes del 'otro': la literatura y los estudios interculturales". En Armando Gnisci (ed.) Introducción a la literatura comparada. Barcelona, Crítica. pp. 347-389.
Morales, José Francisco y Miguel Carlos Moya. 1996. Tratado de Psicología Social. Madrid: Síntesis.

Moura, Jean Marc. 1992. "L'imagologie littéraire, essai de mise au point historique et critique". En Revue de Littérature Comparée. (3): 271-287.

Ortíz, Antonio Domínguez y Bernard Vincent 1979. Historia de los moriscos: vida y tragedia de una minoría. Madrid: Alianza Editorial.

Ricoeur, Paul. 1984. Educación y Política: de la historia personal a la comunión de libertades. Buenos Aires: Editorial Docencia.

.1994. Ideología y utopía (Alberto L. Bixio [trad.]). Barcelona: Gedisa.

Romero, Manuel Sánchez. 2005. “La investigación textual imagológica contemporánea y su aplicación en el análisis de obras literarias". En Revista de Filología Alemana. (13): 9-28.

Said, Edward. 1996. Cultura e imperialismo (Nora Catelli [trad.]). Barcelona: Anagrama.

Taylor, G.H. 2001. Ideología y utopía (conferencias por Paul Ricoeur). Barcelona: Gedisa.

Vargas, Roy Alfaro. 2008. "El concepto de ideología en Paul Ricoeur". En Revista Ciencias Sociales, (1): 154-161.

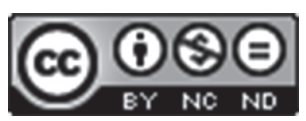

Este obra está bajo una licencia de Creative Commons Reconocimiento-NoComercial-SinObraDerivada 4.0 Internacional. 
